ISSN 2078-6077.

Наукові зошити історичного факультету Львівського університету. 2018-2019. Випуск 19-20. С. 325-338 Proceedings of History Faculty of Lviv University. 2018. Issue 19. P. 325-338

УДК 930.2: 821.161.2-32-94-92 (497.15)“189” А. Чайковський

\title{
БАЛКАНСЬКІ ОПОВІДІ АНДРІЯ ЧАЙКОВСЬКОГО: антиімперські та антивоснні аспекти, сучасний вимір
}

\author{
Богдан ЯКИМОВИЧ \\ Львівський національний університет імені Івана Франка \\ кафедра історичного краєзнавства \\ вул. Університетська, 1, Львів, 79000, Україна \\ e-mail: b.yakymovych@gmail.com
}

\begin{abstract}
Відомого українського письменника, громадського та державного діяча Андрія Чайковського (1857-1935) під час навчання у Львівському університеті на правничому факультеті 1882 р. як офіцера запасу прикликали на дійсну військову службу, оскільки 77-й (Самбірський) полк, до котрого він був приписаний, змобілізували на придушення Боснійського повстання. Власне, спогади про 8-місячну службу в Австро-угорській армії, друк яких розпочато 10 років пізніше від тих подій у часописі “Діло”, започаткували письменницьку діяльність А. Чайковського. Дев’ ять оповідань, які автор цієї студії зібрав та опублікував у першому науковому зібранні мемуаристики та публіцистики А. Чайковського в 4-х томах (Львів, 2002, 2007) є маловідомі українському читачеві і вже зовсім невідомі в Боснії та Герцеговині, і ширше - на Балканах, що завжди були пороховою бочкою Европи, але мають щастя не межувати з Росією. Про значення цих творів для балканістичних студій ідеться в цій статті.

Ключові слова: Андрій Чайковський, Боснія та Герцеговина, Фоча, Дріна, Стоян Ковачевич, Берлінський конгрес.
\end{abstract}

Десять років, які минули від 150-річчя до недавнього 160-річчя від дня народження (2017) Андрія Чайковського, були насичені багатьма подіями, що залишаться знаковими в історії сучасної України. I хоч ніхто зі свідомих та освічених українців ніколи не сподівався ніякого добра від нашого північносхідного сусіда, агресія Росії на чолі з новітнім “царем" В. Путіним у час святкування 200-річчя від дня народження українського Пророка Тараса Шевченка поставила Україну перед вибором: або змобілізувати націю на боротьбу з агресором, або бути на цей раз знищеною не лише як держава, але й як народ. Та поряд зі зброєю, яка, без сумніву, потрібна для стримування напасника, дипломатичними зусиллями з боку України та окремих світових держав, що нам співчувають, Росію може перемогти лише згуртоване, високо свідоме і оснащене сучасною зброєю українське військо.

Творчість Андрія Чайковського, одного $з$ найвідоміших письменників свого часу, на творах якого виховане покоління українського резистансу першої половини $\mathrm{XX}$ ст., залишається актуальною й донині. Спадщина великого українського патріота, попри будь-яку оцінку його творів з боку модерних літературознавців, $\epsilon$ вельми цінною для патріотичного виховання суспільства, зокрема й українських вояків.

Зупинимося коротко лише на головних аспектах його біографії та творчого доробку, який $\epsilon$ цінним не лише для українського народу, оскільки детальніше 3 
ISSN 2078-6077. Наукові зошити історичного факультету Львівського університету. 2018-2019. Випуск 19-20. Proceedings of History Faculty of Lviv University. 2018-2019. Issue 19-20.

оцінкою життя і творчости А. Чайковського можна ознайомитися 3 фундаментального корпусу зібрання його мемуаристики, епістолярію, науковопубліцистичних праць, підготованих Науковою фундацією його імени та виданих Львівським національним університетом імені Івана Франка в чотирьох томах $(2002,2007)^{1}$.

Андрій Чайковський займає почесне місце серед громадських та культурних діячів Галичини кінця XIX - початку XX ст., а його художня та публіцистична спадщина $€$ цінним надбанням українського народу.

Народився письменник 15 травня 1857 р. в Самборі в родині дрібних урядовців. Рано залишився сиротою, виховувався в родичів в с. Гордині коло Самбора. Походив $з$ дрібної шляхти - з дитячих літ добре пізнав життя і побут цієї верстви Галичини, що була основою війська галицьких князів і королів Ці свої спостереження письменник пізніше знаменито відтворив у власних творах.

Початкову освіту отримав удома, далі закінчив Самбірську гімназію, де належав до таємної учнівської громади. В 1877 р. записався на філософський факультет Львівського університету. Не маючи коштів на прожиток, вступив на однорічну військову службу, отримавши офіцерську рангу, а повернувшись до Львова, продовжив навчання на правничому факультеті. У січні 1882 р. як резервовий офіцер був мобілізований до війська на придушення повстання у Боснії. Саме спогади про це стали першим літературним твором, який здобув високу оцінку Івана Франка та став заохотою до подальшої літературної праці.

Після закінчення університету, А. Чайковський працював як адвокат у славному місті Бережанах, де навчався свого часу Будитель краю Маркіян Шашкевич. Саме в цьому місті народилися і виросли його діти (А. Чайковський одружився з Наталею, рідною сестрою відомого на всю Галичину громадського діяча та вченого Дем'яна Гладиловича), тут він написав свої численні твори, співпрацював з часописом “Діло”, фактично став організатором українського життя Бережанщини.

Про високий професіоналізм А. Чайковського як правника свідчать його праці "Процес Ісуса Христа" (1893, написана на підставі Святого Письма, Страсних Євангелій, творів Ернеста Ренана та ін.), “Староатенський процес кримінальний” (надрукована в 1897 р. в “Часописі Правничій”) та деякі інші фахові статті, що побачили світ у різних періодичних виданнях.

1 Достатньо грунтовну наукову біографію письменника автор цих рядків виклав у виданні: Андрій Чайковський: життя, творчість, громадсько-політична діяльність в кн.: Андрій Чайковський. Спогади, листи. Дослідження: У 3 т./ Мін. освіти і науки України, Львівський національний університет ім. Івана Франка, Наукова бібліотека; Національна академія наук України, Інститут українознавства ім. Івана Крип'якевича; Наукова фундація Андрія Чайковського, Упорядкування Б. 3. Якимовича за участю 3. Т. Грень, О. В. Седляра; Редкол.: Б. З. Якимович (голова) та ін. Т. 1., (Львів, 2002), 514.; Т.2, 468.; Т. 3, 576.; Т. 4, (додатковий), (Львів, 2007), 680. Тут і далі поклики на це видання будуть у квадратових дужках із зазначенням тому і сторінок. Біографічні матеріяли див. [1; с. 6-24; 4, 5-8]. 
“Захоплення Козаччиною і любов до України змусили мене заповняти прірву в нашій літературі історичними оповіданнями”, - писав А. Чайковський в автобіографії. Дуже коротко переглянемо цей значний творчий доробок письменника.

Починав свою літературну діяльність А. Чайковський оповіданнями 3 сучасного йому життя. Одначе на другому етапі творчости він фактично повністю поринув у козацьку тематику. До кращого його доробку належать повісті: “За сестрою" (1907), "Віддячився" (1913), "На уходах" (1921), “Олексій Корнієнко” (у трьох частинах) (1926-1929), “Полковник Михайло Кричевський” (1935), “Перед зривом” (1937) та ін.

Найбільшим твором А. Чайковського, саме тим, який автор вважав найголовнішим, є роман “Сагайдачний”, що його задумано в 6-ти частинах. Водночас цей твір мав чи не найбільш нещасливу долю, його переслідувала польська окупаційна влада. В рекламному повідомленні до його історичного нарису “Петро Сагайдачний” (1927) зазначалося, що друкується продовження роману під назвою "Гетьман" як четверта і п'ята частини, та вони світу не побачили. Літературознавець В. Яременко пробував, але без успіху, розшукати рукопис цих частин роману.

За рік до святкування 40-річного ювілею своєї письменницької діяльности, відповідаючи на анкету “Нового Часу”, А. Чайковський написав такі слова: “Я поклав собі за ціль мого життя переповісти в белєтристичній формі здебільшого нашу історію 3 козацького періоду, і тим заповнити цю прогалину в нашій літературі. До того часу мало хто до того брався, праця така вимагає багато труду і студій, а далеко легше фантазувати на теми буденні, з життя". I це завдання він виконав гідно.

Перед самою війною А. Чайковський перебрався мешкати до рідного Самбора, де його зустріли бурхливі події Першої світової війни, Визвольні змагання. Після окупації Самбора російським військом у 1914 р. за доносом місцевих москвофілів його заарештували і ув'язнили у львівській тюрмі “Бригідки".

Одним із найцікавіших біографічних творів А. Чайковського є його “Чорні рядки" - спомини за час від 1 листопада 1918 до 13 травня 1919 р., коли письменник обіймав посаду повітового комісара Західно-Української Народної Республіки у Самборі. Під час перебрання влади на Самбірщині маємо і боснійський “слід”. В організації акції А. Чайковському в с. Корналовичі допоміг його “крігскамрат” (товариш зброї) Микола Грущак, голова читальні “Просвіта" та ще два колишні австрійські підстаршини. серед яких був Осип Струмеляк.

“Чорні рядки”, попри деяку суб’єктивність автора, служать живим джерелом для істориків, які досліджують Визвольні змагання українців. Оригінальність цього твору полягає передовсім у тому, що ми маємо достатньо різного роду воєнних мемуарів того періоду, історичних досліджень, які написали стрільці та старшини Української Галицької Армії. Одначе спогадів, які б показували життя 
ISSN 2078-6077. Наукові зошити історичного факультету Львівського університету. 2018-2019. Випуск 19-20. Proceedings of History Faculty of Lviv University. 2018-2019. Issue 19-20.

провінції очима повітового керівника, свідчень, як організовувалося державне будівництво на місцях, практично немає.

Після падіння Західно-Української Народної Республіки родина Чайковських оселилася в Коломиї. Вже в поважному віці А. Чайковський співпрацював в Українському Національно-Демократичному Об'єднанні (УНДО). Саме на коломийський період життя припаде основна частина, так би мовити, “козацького" періоду творчости А. Чайковського. Але перед Коломиєю був Самбір, місто, де йому судилося стати найвищим представником уряду ЗУНР.

Висновки, чому саме впала у 1919 р. наша молода держава, є справді мудрі i, на жаль, досі актуальні. Якби деякі наші сучасні політики добре прочитали i найголовніше - засвоїли “Чорні рядки”, то бодай би не повторювали тих помилок, які часто-густо маємо у нашому сьогоденні. Брак почуття власних сил до самостійности, наш хворобливий антимілітаризм, манія підозріння, а з іншого боку - наша кари гідна поблажливість на моральні злочини перед власним народом, невільниче наслідування Москви нашими братами на Схід від Збруча, розкидання багатообіцяльних кличів, без урахування того, чи ті ідеї будуть сприйняті нашим народом, вносило деморалізацію і розклад та допомагало більшовикам повалити українську державність на Наддніпрянщині.

Можливо, буду занадто суб'єктивним, але на мій погляд "Чорні рядки" А. Чайковського - один з найкращих зразків української мемуаристики.

Андрій Чайковський помер у Коломиї 2 червня 1935 р. Сумна звістка про смерть заслуженого діяча культури облетіла Галичину. В понеділок, 3-го червня, у Львові зібралася Рада “Товариства письменників і журналістів імени Івана Франка" на своє жалібне засідання. Повідомлення про смерть А. Чайковського розклеїло на мурах Львова також товариство "Просвіта", а на будинку своєї централі, пл. Ринок, 10, на знак жалоби, вивісило чорний прапор. Першу сторінку найповажніших галицьких щоденників “Діло” та “Новий Час" за 6 червня зайняв великий некролог А. Чайковського.

Похорон А. Чайковського 4 червня 1935 р. перетворився на велику маніфестацію українства в давньому культурному центрі Галичини місті Коломиї. Заслужений громадський діяч і письменник знайшов вічний спокій у родовому склепі недалеко від старовинної гуцульської церкви на міському цвинтарі. А незабаром часи настали такі, що його творчість хотіли стерти з пам'яті його народу.

Нашої незалежности нікому не здолати, попри потуги багатьох тих, для кого вона $\epsilon$ “тимчасовою”, хто хоче нас втягнути в нове московське (мадярське чи польське! - $є$ й такі в Україні) ярмо. А для того, щоб і думки в колаборантів та зрадників не було, треба виховувати українців на спадщині таких патріотів, яким був А. Чайковський, застосовувати для боротьби з антидержавними елементами ті сили і засоби, які має держава в законодавчому полі. 
ISSN 2078-6077. Наукові зошити історичного факультету Львівського університету. 2018-2019. Випуск 19-20. Proceedings of History Faculty of Lviv University. 2018-2019. Issue 19-20.

Сподіваємось, що Україна таки спроможеться видати поважне зібрання його творів, бо творчість А. Чайковського має непересічне значення для пробудження національної свідомости і виховання молодого покоління.

Маємо впевненість і в тому, що у Львові та Коломиї вдячні нащадки таки зведуть пам'ятники своєму славному синові Андрієві Чайковському. Символічно, що в Самборі, на малій батьківщині письменника, пам'ятник закладено у першу річницю незалежности України. Монумент у Самборі відкрито до третьої річниці відродження нашої держави, 24 серпня 1994 р., а в Бережанах - до п’ятої, у 1996 р. Але найвеличнішим пам'ятником усім патріотам буде розбудова держави України, яка й досі, на очах европейської демократії страждає від агресії свого споконвічного ворога Росії, стаючи вкотре, перефразовуючи слова Ліни Костенко, гранітним щитом уже сьогочасної, але недалекоглядної Европи.

Як уже відзначено вище, резервовий поручник австро-угорської армії Андрій Чайковський, тодішній студент Львівського університету у 1882 р. був прикликаний на дійсну військову службу і скерований приборкувати антиавстрійське повстання до Боснії і Герцеговини. Ставлю собі завдання дати сьогодні оцінку лише незначній частині письменницької спадщини А. Чайковського, а саме - балканським оповідкам.

Цих оповідань є дев'ять: сім частин “Споминів 3-перед десяти літ” (побачили світ в газеті “Діло” 1894 р., окреме видання 1897 р.) та ще дві новели: "Seid’s einmal ein Friedensapostel” (вперше надрукована з рукопису, що належав внукові письменника Андрієві Ставничому в згаданому вище нашому виданні [1; с. 150-153] та “Коли раз серце кров'ю обкипить...” (першодрук у Літературно-науковому вістнику, 1910) [1; $154-160]$. Уся ця маловідома навіть для українського загалу творчість А. Чайковського $є$ вельми цінною не лише для нас, але й для балканських народів, яких стосується безпосередньо і яку ми зобов'язані, через переклади сербською і англійською мовами, їм донести.

До речі, “Спомини з-перед десяти літ" - одна з найрідкісніших книжок з усіх творів А. Чайковського, бо до нашого часу дійшли лише лічені ії примірники [3; c. 302]. Тому наше перевидання не лише врятувало їх від дуже ймовірного забуття, вони стали доступні сьогодні принаймні українському читачеві, а, сподіваюся, згодом дійдуть і до читачів на Балканах та в інших країнах світу [1; с. 28-149].

У чому я вбачаю особливу цінність згаданих дев'яти оповідань? На мій погляд, найголовніша їх риса - це, насамперед, людяність до підлеглих військовиків, несприйняття тих представників інших народів Австро-Угорської монархії мадярів, поляків, врешті й деяких інших, які не визнавали для українців права на власну самоідентифікацію. А ще - усвідомлення неправедливости своєї місії в Боснії і Герцеговині, бажання пізнати культуру та звичаї місцевого населення, співчуття до їхніх проблем і страждань через окупацію рідних земель АвстроУгорщиною (“цивілізованим Віднем”) після відходу турків. 
ISSN 2078-6077. Наукові зошити історичного факультету Львівського університету. 2018-2019. Випуск 19-20. Proceedings of History Faculty of Lviv University. 2018-2019. Issue 19-20.

Навіть поза описаними в оповіданнях окремими трагічними фактами, які зображено чесним пером автора, читач побачить у цьому циклі новел ту величезну несправедливість, що дозволяють собі сильні держави щодо поневолених народів.

Для кращого розуміння ситуації $є$ потреба навести тут кілька думок про т. зв. Берлінський конгрес, який відбувався впродовж місяця - від 13 червня до 13 липня 1878 року, скликаний після завершення російсько-турецької війни 1877 1878 pp. Та війна закінчилася підписанням 3-го березня 1878 року т. зв. СанСтефанського мирного договору, вигідного для Російської імперії. Як відомо, попередня імперіялістична війна з Туреччиною, яку в 1853-1856 pр. провадив Микола I (увійшов в історію як Ніколай Палкін, а за визначенням Т. Шевченка “неудобозабываемый тормоз”), війна, якій на перешкоді Росії на півдні Европи поряд з Туреччиною стали Англія і Франція, закінчилася повним фіяском для російських планів. Його наступник, Олександр II $^{2}$, провівши Велику реформу та зміцнивши імперію, не полишив московських традицій здобувати нові території. Але Англія та Франція на той раз знову стали на перешкоді російським апетитам, тому того ж, 1878 р., Росія змушена була взяти участь у роботі згаданого вище Берлінського конгресу. Йому передувало ще три угоди: таємна англо-російська умова, конвенція між Англією і Туреччиною про передання Англії Кіпру та англоавстрійська угода, яка погоджувала загальну лінію поведінки цих політичних гравців на Берлінському конгресі. Формально, Берлінський конгрес мав на меті поділити землі та зони впливу після Паризької мирної угоди 1856 року. Головував на конгресі Бісмарк, який оголосив себе “чесним маклером”, тобто нейтральним посередником. I хоч справді Пруссія на той час практично ні на що не претендувала, видатний німецький політик, батько об'єднаної Німеччини, не будьмо наївними, працював над перспективними завданнями майбутнього німецької нації.

У результаті того міжнародного форуму, який дозволив головним европейським гравцям встановити на свій розсуд нові кордони на континенті, на його карті виникла незалежна держава Румунія, зліплена англійцями і французами з трьох колишніх незалежних князівств - Валахії, Трансільванії та Молдавії, i яка навіть спочатку не знала, як себе назвати. Взявши собі напівлегендарну історичну назву (а їм так щастило не раз!), іiі народ не пролив за свою незалежність фактично ні краплі крові. Натомість окупація Австро-Угорщиною Боснії та Герцеговини призвела до кривавих подій, які в кінцевому підсумку, зумовленому анексією краю до складу монархії в 1908 р., стали зачіпкою до початку світової війни 1914 року.

\footnotetext{
${ }^{2}$ Цей найбільший в історії Росії “ліберал” з усіх іï імператорів, підписав т. зв. Емський указ, який повністю забороняв право українського народу на його мову, освіту, книжку.
} 
ISSN 2078-6077. Наукові зошити історичного факультету Львівського університету. 2018-2019. Випуск 19-20. Proceedings of History Faculty of Lviv University. 2018-2019. Issue 19-20.

Однією з найцікавіших частин “Споминів 3-перед десяти літ” $є$ VII їх частина під назвою “Христос воскрес”, де йдеться про те, як провів Великдень 1882 р. свідомий українець, офіцер австрійської армії А. Чайковський зі своїми жовнірами в окупованій Боснії. У Великодню суботу він отримав наказ вийти з Фочі до містечка Брод, де недавно була битва 3 повстанцями. Тоді загинув один австрійський офіцер. Далі цитую А. Чайковського: “....наша гірська батерія після оповідання очевидців - ціле містечко до нащадку зруйнувала” [т. 1, с. 141]. Після цікавого опису перемаршу компанії (сотні), живописного малюнка гірської місцевости підрозділ прибув виконувати завдання на місце. А. Чайковський вміє добре підмічати деталі, з великою художньою майстерністю подає реальні факти, які приносить мешканцям війна.

Ось як описує він зруйновану хату місцевого мешканця, яка прилягала до облаштованого ними табора: "Входжу до сіней виломаними дверми. В сінях повно потовченого череп'я, розбиті якісь судини бондарські, вивернені на бік і поломані жорна. В хаті виломані двері також, піч розвалено, повно череп'я, вивернена горі дном колиска, трохи соломи і якісь лахи, поломаний стілець, а на середині помосту діра, завбільшки як голова чоловіка. Тут - гадаю - або чорт женився, або й сам газда, утікаючи все понищив, щоб не дісталося в руки “шваба". Але звідки та діра взялася? Гляджу, а така сама діра в повалі і в даху. Все ж, очевидно гарматна куля так справилася, то аж три діри вибила! Цікавість бере мене: де та куля ділась? - і лізу в пивницю. Тут також руїна, бо тут саме експльодував гранат, - от находжу ще від ломки заліза в стінах пивничного муру, а от забита кітка лежить на купі гнилих бараболь. Чи приснилось коли біднязі, що згине такою лицарською смертю? Мене пройняв якийсь гробовий холод, жах і жаль - та вже ж не за кіткою... Я вийшов на двір з другого боку хати. Тут була колись пасіка. Який десяток пнів вивернених, поломаних, довкола кождого розлазилися бджоли - вони погинули на морозі” [т.1, с. 144] .

Далі письменник вдається до моральної оцінки цієї матеріяльної руїни: “Ось тобі війна?.. Мені не раз лучалося читати про війну та їі руїну, але чи міг я собі уявити: що воно таке в дійсності? Одна зруйнована оселя показала мені се наглядно. Кілько то коштувало труду бідного герцеговенця, заки поставив таку хату, завів садок, пасіку... А все зруйнувала одна драча воєнна, один фунт пороху, один т. зв. Hohlgeschoss!. А скільки тут сліз пролито, коли прийшлося з тої гірської хатини утікати з самим лише життям! I задля чого? Бо так хотів Берлінський конгес. Я пригадав собі Шевченкові слова:

...Люде, люде!

Коли то з вас буде

Того добра, що маєте?” [т. 1, с. 144].

Хтось, не задумуючись, скаже: подумаєш, побачив зруйновану хату та й здивувався! Але ця хата зруйнована чужими загарбниками на чужій землі. А скільки таких зруйнованих хат на українському Донбасі, куди, всупереч будь- 
ISSN 2078-6077. Наукові зошити історичного факультету Львівського університету. 2018-2019. Випуск 19-20. Proceedings of History Faculty of Lviv University. 2018-2019. Issue 19-20.

якому міжнародному праву і без усяких навіть конгресів уже понад чотири роки господарює московський окупант. Так і хочеться нагадати безсмертний заклик Ю. Фучіка до всього світу: “Люди, будьте пильними!”

На мій погляд, найтрагічнішою оповідкою про одне знищене війною життя $\epsilon$ новела “Коли раз серце кровію обкипить...”. Сюжет ії простий. Один товариш автора, кадет, чех за національністю, націоналіст, радше щирий чеський патріот Гроссман запропонував піти з ним у гості на фочанський сербський варош частину Фочі, де жили православні. Цікавий штрих до портрета Гроссмана: від наших жовнірів він вивчився по-українськи, а від сербів - по-сербськи [т.1, с.154].

Вони прийшли до сербської родини, яка мала всі підстави ненавидіти людей в уніформі чужої держави, але лише запевнення товариша, сербська мова А. Чайковського розтопила лід після входу до них невідомого офіцера. Господар Сімон мав двох дочок, старша з яких Мара. Вона вийшла заміж за молодого священика Петра, про яких Гроссман сказав що “любилися так, як лише може любити серце, що виросло під полудневим горячим сонцем” [1: с. 159]. Петра заарештували за участь в таємній протиокупантській організації. Коли його вели на страту, він вів себе гордо, йшов 3 піднесеною головою та підбадьорював товаришів недолі. Не витримав лише тоді, коли з ним прийшла попрощатися Мара. Цей мужній чоловік не витримав, цитую:

"Маро мойа драга, ті! - говорив він, ридаючи. Пригортав їі ніжно до грудей, гладив по лиці - не плач дитино, так мусить бути, ми не надовго розлучаємося, зійдемось там у праведного Бога, не плач жінко, я не жалую того, що я зробив. Тут треба крови моєї, з неї виростуть месники. Не плач, не забувай за мене, постав на моїм гробі хрест і помолись за мене, ну годі, прощай!”

На площі цілій, а народу було страх - розляглось страшне голосіння. Що ти скажеш? Старий капітан Гейсс, той покірний чоловік, - i йому капнула сльоза на сиву бороду...

Мара зомліла. Її винесли з того чортового четверокутка мертвою. Я справді думав, що вона вмерла, се би було для неї найліпше.

Тепер бідна мучиться лише. Яке ії життя? Знаєш, що один з тих жовнярів, що його заставили стріляти, третього дня застрілився. Бо справді, вбивати таке молоде життя, то щось більше, чим варварство...Тю!

Я не можу себе повздержати, щоб не зайти деколи до старих. I все застаю те саме. Мара нидіє з дня на день...

- А тим, що підписували берлінський трактат і на думку не прийде се зломане життя, - кажу я...” [ 1; с. 159-160].

Скільки раз читаю цю невигадану історію однієї родини, завжди на очі напливають сльози, а серце справді обливається кров'ю від ненависти до кожного окупанта, до всяких “собірателів чужих земель”, до тих, котрі через імперське затемнення розуму, не вважає своїх сусідів навіть нацією та державою. Якби 
люди, які волею долі опинившись на високих посадах, але були людьми, прочитали такого роду твори (а таких свідчень у світовій літературі немало! $)$ - вони мали б забути про всяку окупацію чужих земель і народів. А опис жорстокости, 3 якою розправляється окупант над захисниками свого рідного краю і що подав А. Чайковський у 6-й частині “Споминів..." під назвою "Standrecht”! Чому це продовжується у. здавалося б, цивілізованому XXI ст.? I чому народ, на території замешкання якого створено багато шедеврів світової літератури, сьогодні переважною більшістю підтримує дії свого президента, який погрожує світові ядерною зброєю, а його дії спрямовані на повне знищення цивілізації на планеті? ${ }^{4}$ Адже не стане на землі не лише Києва і Львова, але й Парижа, Брюсселя, Лондона і Риму, не буде Нью-Йорка і Вашингтона, Москви і Петербурга, не стане планети Земля? То хіба цього прагне путінська Росія? Знову згадуються слова Ю. Фучіка...

У цьому творі, як і в усіх боснійських оповідях, згадано про кару, якою карали серби своїх зрадників: їм відрізали ніс, вуха, на чолі вирізували знак і відпускали. "Се у них гірше смерти, бо такому назначеному босняк не подасть води, не то що...” [1, с. 159]. Жорстоко? Так, навіть дуже! Але, мабуть, таки справедливо... зрадники і колаборанти на це таки заслуговують... хай про це пам’ятають!

Я згадував про твір “Seid’s einmal ein Friedensapostel”, уперше опублікований у нашому виданні $з$ рукопису. Там йдеться, що весною 1882 р. цісар Франц Йосиф оголосив амністію: усі провини тих, що брали участь в повстанні, прощаються, кожний усташі (повстанець) може повертатися додому і ніхто до нього не може мати претензій.

Вдамся до цитування: “Той маніфест у мові німецькій, хорватській і сербській порозліплювано в полудневій Боснії і цілій Герцеговині, відчитувано його по сербських церквах, мошеях муслемських, по ярмарках (пасар) і т. ин. А опріч того розсилали гарнізони військові чети під командою офіцерів, розуміючих місцевий говір ${ }^{5}$, по околиці від села до села. Вони мали не лише проголосити

\footnotetext{
${ }^{3}$ Поруч зі справді геніяльними антивоєнними творами Ернеста Гемінгвея чи Еріха Марії Ремарка закордонному читачеві вартувало б знати не менш геніальний антивоєнний твір українського письменника Осипа Туряннського "Поза межами болю" (перше видання Львів, 1921, одночасно нім. переклад).

${ }^{4}$ Про хижі наміри Путіна супроти Чечні, Грузії, України і взагалі - супроти европейської цивілізації йдеться у глибоко аналітичній книжці американського вченого Херпена М.Х.Ван, котра нещодавно побачила світ в Україні - див.: Херпен М. Х. Ван. Війни Путіна. Чечня, Грузія, Україна: незасвоєні уроки минулого, (Харків: Віват, 2015), 304. Ця книжка дуже цінна ще й тим, що подає дуже багато, в основному англомовної літератури, яка стосується минулого і сучасного Росії, ментальности російського народу.

${ }_{5}^{5}$ Офіцерові А. Чайковському було достатньо кількох місяців, щоб добре вивчити сербську мову, а згадаймо наших “братів», які повернувшись до Галичини в далекому 1944 р. й до сьогодні не хочуть говорити українською. Ми мовчимо вже про народжених в Україні ії̈ громадян, які чомусь вперто користуються мовою окупанта.
} 
ISSN 2078-6077. Наукові зошити історичного факультету Львівського університету. 2018-2019. Випуск 19-20. Proceedings of History Faculty of Lviv University. 2018-2019. Issue 19-20.

народові маніфест, але також і перевести роззброєння населення, себто забрати огнену зброю" [1, с. 150].

У цій коротенькій новелі маємо чудовий опис герцеговинської природи, ріки Дріни, гірських околиць, які врізалися авторові в пам'ять з такою силою, що він відтворює їх вже на схилку свого віку, порівнює балканські гори з карпатськими. Та звертаю увагу зовсім на інше: як своєю доброю настановою та повагою до місцевого люду, поручник австро-угорської армії, переконаний український патріот і людинолюб Андрій Чайковський виконав доручену справу, не образив нікого, не підставив під повстанські кулі своїх підлеглих, щасливо вернувся до Фочі. А ось цитата знову: “Але не всім “апостолам миру” пішло так гладко, як мені. Були й такі, що брались до населення гостро, стрічали на опір і пустили кілька сіл $з$ димом, побили людей ${ }^{6}$. Ті нічого не привезли, хіба по кілька поломаних крісів, які забрали силою" [1; с.153].

То й справді, не всі стають Апостолами, бо ними стати не просто без необхідної умови - бути Людиною, а не звіром у людській подобі... Про достатні умови для цієї теореми тут навіть не йдеться...

Коли йдеться про вартість балканських оповідань А. Чайковського, слід пам'ятати, що восьмимісячне перебування його в Боснії і Герцеговині не стало просто незначним епізодом його життя, а сильно вплинуло на його свідомість та життьову мудрість. Лише один дрібний штрих: ми маємо повне право вважати А. Чайковського одним із тих діячів, які були дуже близько до галицького театру "Руської Бесіди", ба, навіть одним з його творців - про це наша стаття “Театр «Руської Бесіди» і Андрій Чайковський” [3; с. 413-427]. На основі практики військової служби на теренах Боснії у статті “Про потребу українського людового театру”, через відсутність придатних для вистав приміщень у провінції А. Чайковський пропонує цілком реальну для виконання конструкцію мандрівної споруди, 3 котрою “. ...можна заїхати на вистави у кожну закутину нашої Вкраїни” [4; c. 542].

Насамперед, дуже шкода, що пропала вельми цінна частина документальної спадщини А. Чайковського часів його перебування на Балканах. У листі до

\footnotetext{
${ }^{6}$ Ох, скільки таких “героїв” було за останньої радянської окупації в Афганістані, але як мало про це чесно написаних споминів! Громадянин України Юрій Чернишов, колишній полковник ГРУ генштабу ЗС СРСР, автор ганебної книжки, яка побачила світ 2016 р. в Житомирі під назвою “Одной крови”, надрукував відкрито, у стилі збіглого державного злочинця Д. Табачника, ганебний трактат супроти галичан, спрямований на розкол держави. Але тут навіть не про те. Значну частину надрукованого присвячено його “афганським подвигам”, де нема жодного доброго слова про нещасних афганців, на теренах яких доблесні московські вояки палили цілі села разом 3 жінками та дітьми. У російських вояків, як було за колишнього СРСР, всі місцеві люди для них лише бандити. Не знаю досі, чи СБУ України притягнула до юридичної відповідальности цього та йому подібних антиукраїнських писак, які сьогодні є відвертою “п”ятою колоною” Кремля в Україні.
} 
М. Павлика від 20 січня 1894 р., де він описує свої плани щодо своїх боснійських оповідань, зазначивши, що планує поодинокі образки з життя українських вояків, а також розвідку про босансько-герцеговинський народ, $\epsilon$ така прикра правда: "На тім, либонь, буде конець спогадів, бо вже, мовляв, викричався, а записок ніяких не маю. Якби були не пропали мої листи аркушеві, писані з Боснії до мого покійного швагра Дамяна Гладиловича - можна багато цікавого пригадати. Та бачите, ті листи були писані в пору процесу Ольги Грабар 7 , то покійний, боячись, щоб они при ревізії не попали в непокликані руки, усі спалив" [2; с.22]. Дуже шкода, бо ці документи придалися б для сучасних істориків України та Боснії й Герцеговини.

Саме військова служба, розуміння ролі і вартости власної армії дала право повітовому комісарові Західно-Української Народної Республіки Самбірщини А. Чайковському написати та надрукувати для воїнів УГА своє знамените “До українських жовнірів моє дружнє послання” - публіцистичний, контрпропагандистський твір, де він громить ворожу пропаганду, розвінчує порожні обіцянки ворога, спрямовані лише на дезорганізацію наших оборонців, пояснює ролю інтелігенції - еліти нації в здобутті та будівництві держави. Він справді мав право на такі слова: “... до вас промовляє старий жовнір і офіцер зперед 41 років, вихований в твердій жовнярській школі з далекого часу, як вас ще на світі не було... Я служив чужій, ворожій нам державі; які ви щасливіші від мене, що служите тепер своїй українській народній Республіці! О тім повинен кожний $з$ вас тямити, встаючи і лягаючи, і повинен дякувати Богові, що такої щасливої хвилі діждав...” [1; с.349-350]. Якими актуальними $€$ ці слова i, власне, уся книжечка А. Чайковського в наші дні Вітчизняної війни проти хижої Москви.

А ось, що пише А. Чайковський в листі до С. Єфремова 27 липня 1902 р., уточнюючи свою біографію: “... коли я був на IV курсі правничого факультету, мій полк змобілізували і я пішов, яко резервний поручник (лейтенант), утихомирювати босансько-герцеговинське повстання (Господи! Прости мені гріх сей!). Там я був 8 місяців, а відтак вернувши, поскладав іспити державні і рігорози докторські, відбув 7-літню практику і став адвокатом такі відразу в Бережанах, де і тепер живу" (потовщення моє - Б. Я.) [2; с.128]. Як бачимо, свою службу в чужій армії, боротьбу проти повстання чужого народу, проти окупантів український патріот вважав за гріх. Аналогічні думки він висловлював у листах до І. Франка, М. Коцюбинського, О. Маковея та до інших діячів культури.

На наш погляд, цікавими $є$ оцінки політично ситуації в Европі, i, зокрема, на Балканах, яку він дає в статті “На біжучі теми”, опубліковану вперше в газеті

\footnotetext{
7 Тут мова про процес проти москвофілів, який відбувався 1881 р. у Львові. Головною обвинуваченою була Ольга Грабар, дочка Адольфа Добрянського. Д. Гладилович боявся, щоб листи А. Чайковського, де була гірка правда про урядову політику Австро-Угорщини на Балканах, наші вороги - поляки та москвофіли, не використали проти українців Галичини.
} 
ISSN 2078-6077. Наукові зошити історичного факультету Львівського університету. 2018-2019. Випуск 19-20. Proceedings of History Faculty of Lviv University. 2018-2019. Issue 19-20.

“Діло”1912, № 272 від 3-го грудня (перший наклад). Справа в тому, що цю статтю повністю сконфіскувала прокуратура, наклад заарештовано, а другий наклад вже був без неї. Нам пощастило розшукати в Науковій бібліотеці Львівського національного університету примірник з конфіскованого накладу та опублікувати цю статтю в нашому виданні. Там справді $є$ оригінальні судження про Боснію та Герцеговину, про таку відому на Балканах фігуру, як Милян Обренович та ін. [4; c.544-547.]. Словом, 3 думами про Балкани А. Чайковський жив усе життя.

А тепер висновки з викладеного:

1. Балканські оповідки Андрія Чайковського залишаються і на сьогодні маловідомими шедеврами художньо-мемуарної літератури в Україні та практично невідомими за іiі межами, насамперед в тому краї, про терени якого в них йдеться.

2. Написані на основі особистих вражень пером талановитого письменника, який молодим зафіксував у своїй пам'яті трагедію Боснії та Герцеговини, відтворені на папері у зрілому віці, мемуарні оповідки А. Чайковського є зразком першокласної антивоєнної та антиімперської прози европейського рівня.

3. Маючи замилування до історії, А. Чайковський дуже точно фіксував не лише події, учасником яких був, а, найголовніше, настрої та трагедії місцевого населення, спричинені австрійською окупацією краю на підставі Берлінського конгресу 1878 року, як також і трагедії тих, кого доля закинула виконувати волю окупантів на чужій землі.

4. Дослідники перебігу боснійського повстання 1882 року. ознайомившись 3 цією частиною спадщини А. Чайковського, зможуть додати низку цікавих штрихів як до характеру повстанців (провідника Стояна Ковачевича та його майже дитинного романтизму і середньовічної порядности у стосунках з ворогами свого народу, рядових повстанців), так і до розуміння ситуації в цілому.

5. Імперські амбіції Габсбурзького роду привели до закладання міни сповільненої дії на Балканах, що спрацювала 28 червня 1914 року в Сараєво i стала зачіпкою для початку Світової війни, в яку невдовзі було втягнуто 48 із 59 країн світу.

6. Вважаю, що переклад сербською, хорватською та англійською мовами оповідок А. Чайковського, можливо - окремих публіцистичних матеріялів, не лише дасть потрібну та невідому для Балканського регіону, батьківщини Нобелівського лауреата Іво Андрича, фактологічну інформацію про події 1882 року, а й упровадить творчість А. Чайковського в европейський контекст.

I, насамкінець, ще одна вкрай важлива і зрозуміла для всієї української патріотичної інтелігенції справа, та чомусь незрозуміла для таки освіченого найвищого керівництва нашої держави. Йде п'ятий рік війни проти агресії нашого 
споконвічного ворога, що не заспокоїться доти, поки нас не поборе, або допоки не розвалиться його хижа держава. Маємо приклад держави Ізраїль, яка вміє себе захистити перед значно більшою кількістю ворогів, ніж співвідношення Україна-Росія, то переймаймо в них досвід!

Читаймо й учімося в Андрія Чайковського! Будьмо пильні!

\title{
THE BALKAN STORIES OF ANDRII CHAIKOVSKYI: ANTI-EMPIRE AND ANTI-WAR ASPECTS (THE MODERN-DAY DIMENSION)
}

\author{
Bohdan Yakymovych \\ Ivan Franko National University of Lviv \\ Department of Local History \\ e-mail: b.yakymovych@gmail.com
}

Andrii Chaikovskyi (1857-1935), a prominent Ukrainian writer, public figure and statesman, was drafted to a military service as an officer of reserve in 1882 when he was a student of Law at Lviv University. The $77^{\text {th }}$ (Sambir) Regiment, to which he was ascribed, was mobilised for suppressing a revolt in Bosnia-Hercegovina. It was these memoirs about the 8-month-long service in the AustroHungarian Army with, which Chaikovskyi commenced his carrier as a writer. The publishing of the memoirs started in "Dilo" magazine 10 years since the actual events had taken place. Nine stories, collected and published by the author of this study in the first academic collection of Chaikovskyi's memoirs and journalistic works in 4 volumes (Lviv 2002, 2007), are little-known to the Ukrainian reader, while completely unfamiliar in Bosnia-Hercegovina and the Balkans in general. The Balkans have always been Europe's tinderbox, but are lucky enough not to border with Russia. The meaning of these works for Balkan studies and their place in the Ukrainian and world literature is the focus of the present article. The author introduces the reader to Chaikovskyi's biography and writing career, highlighting his contribution to memoir literature: "Spomyny z-pereddesiaty lit" ("Memoirs from the previous decades"), "Chorniriadky"("Black Rows"); and historic prose: stories "Za sestroiu", ("Sister"), "Viddiachyvsia"("Payed Back"), "Na ukhodakh" ("On seasonal works"),”Oleksii Korniienko", "Polkovnyk Mykhailo Krychevskyi” ("Colonel Mykhailo Krychevskyi”), "Pered zryvom”("On the Eve of the Revolt"), and novel "Sahaidachnyi". His stories on the life of the highland Ukrainian nobility, which protected the Ukrainian state during the Princely period, occupy a special place in the Ukrainian literature. Himself being a representative of this stratum of the Halychyna population by origin, he, as anyone else in the Ukrainian literature, attained a true depiction of the former elite of the Ukrainian highland population, its life and values in the modern times. The Ukrainian people and the statesmen have to be acquainted with and appreciate the precautions voiced by Chaikovskyi concerning the causes of the loss of the Ukrainian statehood in 1917-1921. His selected works, after respective translations into Serbian, Croatian, English, German etc., will certainly appeal to many readers outside Ukraine.

Keywords: Andrii Chaikovskyi, Bosnia-Hercegovina, Foča, Drina, Stojan Kovačević, the Congress of Berlin. 
ISSN 2078-6077. Наукові зошити історичного факультету Львівського університету. 2018-2019. Випуск 19-20. Proceedings of History Faculty of Lviv University. 2018-2019. Issue 19-20.

\section{REFERENCES}

Andriy Chaikovskyi. Spohady. Lysty. Doslidshennya (Memoirs. Letters. Studies)/ Ministerstvo osvity i nauky Ukrainy, Lvivs'kyi nacionalnyi universytet imeni Ivana Franka, Naukova biblioteka; Nacionalna Akademiya Nauk Ukrainy, Instytut Ukrainoznavstva imeni Ivana Krypyakevych; Naukova fundaciya Andriya Chaikovs'koho/ Uporyadkuvannya B.Z. Yakymovycha za uchastyu Z.T Hren', O.V. Sedlyara; Redkolehiya: B. Z. Yakymovych (holova) ta inshi. Lviv, 2002.

V.1.514.;

V.2.468;

V.3.576.;

V. 4 (dodatkovyi). Lviv, 2007, 680. 